\title{
Estimation of metabolic heat production and methane emission in Sahiwal and Karan Fries heifers under different feeding regimes
}

\author{
Sunil Kumar ${ }^{1}$, S. V. Singh ${ }^{1}$, Priyanka Pandey ${ }^{1}$, Narendra Kumar ${ }^{2}$ and O. K. Hooda ${ }^{1}$ \\ 1. Dairy Cattle Physiology Division, ICAR-National Dairy Research Institute, Karnal, Haryana, India; 2. Livestock \\ Production and Management Division, ICAR-National Dairy Research Institute, Karnal, Haryana, India. \\ Corresponding author: Sunil Kumar, e-mail: dr.sunil8507@gmail.com, \\ SVS: sohanvir2011@gmail.com, PP: drpriyankapandey12@gmail.com, NK: narendrakumarvet@gmail.com, \\ OKH: hoodaomkanwar1@gmail.com \\ Received: 16-01-2016, Accepted: 12-04-2016, Published online: 24-05-2016
}

doi: 10.14202/vetworld.2016.496-500 How to cite this article: Kumar S, Singh SV, Pandey P, Kumar N, Hooda OK (2016) Estimation of metabolic heat production and methane emission in Sahiwal and Karan Fries heifers under different feeding regimes, Veterinary World, 9(5): 496-500.

\begin{abstract}
Aim: The objective of this study was designed to estimate the metabolic heat production and methane emission in Sahiwal and Karan Fries (Holstein-Friesian X Tharparkar) heifers under two different feeding regimes, i.e., feeding regime-1 as per the National Research Council (NRC) (2001) and feeding regime-2 having 15\% higher energy (supplementation of molasses) than NRC (2001).

Materials and Methods: Six $(n=6)$ healthy heifers of Sahiwal and Karan Fries with 18-24 months of age were selected from Indian Council of Agricultural Research-National Dairy Research Institute, Karnal. An initial 15 days was maintained under feeding regime- 1 and feeding regime- 2 as adaptation period; actual experiment was conducted from $16^{\text {th }}$ day onward for next 15 days. At the end of feeding regimes (on day $15^{\text {th }}$ and $16^{\text {th }}$ ), expired air and volume were collected in Douglas bag for two consecutive days (morning [6:00 am] and evening [4:00 pm]). The fraction of methane and expired air volume were measured by methane analyzer and wet test meter, respectively. The oxygen consumption and carbon dioxide production were measured by iWorx LabScribe2.
\end{abstract}

Results: The heat production $(\mathrm{kcal} / \mathrm{day})$ was significantly $(\mathrm{p}<0.05)$ higher in feeding regime- 2 as compared to feeding regimen-1 in both breeds. The heat production per unit metabolic body weight was numerically higher in feeding regime-1 than feeding regime- 2 ; however, the values were found statistically non-significant $(\mathrm{p}>0.05)$. The energy loss as methane $(\%)$ from total heat production was significantly $(\mathrm{p}<0.05)$ higher in feeding regime- 1 . The body weight $(\mathrm{kg})$, metabolic body weight $\left(\mathrm{W}^{0.75}\right)$, and basal metabolic rate $\left(\mathrm{kcal} / \mathrm{kg}^{0.75}\right)$ were significantly $(\mathrm{p}<0.05)$ higher in feeding regime- 2 in both breeds.

Conclusions: This study indicates that higher energy diet by supplementing molasses may reduce energy loss as methane and enhance the growth of Sahiwal and Karan Fries heifers.

Keywords: feeding regimes, heat production, Karan Fries, methane emission, Sahiwal.

\section{Introduction}

The feeding system that meets animal's energy requirements may result in the productivity of livestock to meet expectations of performance. The level of heat production and methane emission depends on type and level of feed intake. The heat production can be estimated from the oxygen $\left(\mathrm{O}_{2}\right)$ consumed, carbon dioxide $\left(\mathrm{CO}_{2}\right)$, and methane $\left(\mathrm{CH}_{4}\right)$ produced by the animal using Brower's equation. The level of metabolic heat production in domestic animals depends on their feed intake and muscular activity [1]. Increasing the energy levels and/or feeding additive concentrate supplements can improve energy efficiency and thus improve animal performance [2]. Methane is produced by the fermentation process, and it is considered as the

Copyright: Kumar, et al. Open Access. This article is distributed under the terms of the Creative Commons Attribution 4.0 International License (http://creativecommons.org/licenses/by/4.0/), which permits unrestricted use, distribution, and reproduction in any medium, provided you give appropriate credit to the original author(s) and the source, provide a link to the Creative Commons license, and indicate if changes were made. The Creative Commons Public Domain Dedication waiver (http://creativecommons.org/ publicdomain/zero/1.0/) applies to the data made available in this article, unless otherwise stated. inherent part of the energy metabolism in ruminants. Methane conversion rate ( $\%$ of methane energy loss per gross energy intake) ranges from $8.4 \%$ to $10 \%$ in beef cattle [3]. The production rate of enteric methane can vary depending on the digestibility of the animals and the level of feed intake, breed, species, addition of lipid or ionophores to the feeds, alterations in microflora, and different animal activities [4]. Considerable efforts have been made to improve feed utilization and controlling ruminant methane emission [5]. Methane is formed during the fermentation of the feed in the rumen, and the amount is dependent on the quality and quantity of the diet.

The loss of ingested energy as eructated methane in cattle is around 6\% [6], so it is necessary to find the feeding strategies that decrease methane emissions which would not only reduce the emissions of this greenhouse gases to the atmosphere but also improve the efficiency in terms of feed energy utilization in cattle production systems.

Since the interaction effects of energy intake levels on metabolic heat production and methane 
emission rate in Sahiwal and Karan Fries heifers has not been evaluated yet, so this study was carried out using Sahiwal and Karan Fries heifers to estimate the metabolic heat production and methane emission rate under different feeding regimes.

\section{Materials and Methods}

\section{Ethical approval}

The experiment was approved by the Institutional Animal Ethics Committee constituted as per the article No. 13 of the CPCSEA rules, laid down by Government of India.

\section{Study area}

The experiment was conducted in the cattle yard of Indian Council of Agricultural Research-National Dairy Research Institute (ICAR-NDRI), Karnal, Haryana, India, altitude of $250 \mathrm{~m}$ above mean sea level and at $29^{\circ} 42^{\prime} \mathrm{N}$ latitude and $79^{\circ} 59^{\prime} \mathrm{E}$ longitudes. The highest temperature goes up to $45^{\circ} \mathrm{C}$ in summer and minimum temperature $3.5-4^{\circ} \mathrm{C}$ in winter. The average rainfall is about $700 \mathrm{~mm}$.

\section{Animals and experimental design}

Apparently 12 healthy Sahiwal and Karan Fries heifers (18-24 months) were selected from the Livestock Research Centre of ICAR-NDRI, Karnal, Haryana, India. The experimental animals were maintained as per the standard practices followed at the institute farm. The experimental animals were kept in separate shed throughout the experiment. Animals were let loose every week for exercise. The experiments on both groups of animals were conducted for 45 days under feeding regime- 1 as per National Research Council (NRC), 2001 [7] and feeding regime-2 (15\% higher energy level over and above the NRC, 2001 by supplementation of molasses) [7]. These animals were maintained on feeding regime- 1 for 15 days continuously and later on shifted to feeding regime- 2 (15\% higher energy level) for next 15 days continuously. The experimental animals were given adaptation period of at least 15 days before actual experimentation. The feeds offered to the animals and residue left were recorded fortnightly interval to find out the total dry matter intake and ad-libitum water was given to the animals to find out the total water intake. All the animals before actual experimental work were trained to inspire and expire through a three-way valve and putting a face mask to collect expired gas and analyzed for $\mathrm{O}_{2}$ consumption, $\mathrm{CO}_{2}$, and methane $\left(\mathrm{CH}_{4}\right)$ production. These animals were also trained to stand quietly in a wooden Travis for collection of gases before actual experiment.

\section{Collection of expired air sample}

A three-way valve and face mask were used to collect expired air from experimental animals. The recording of $\mathrm{O}_{2}$ consumption and production of $\mathrm{CO}_{2}$ and $\mathrm{CH}_{4}$ was carried out for two days continuously in morning and evening after the end $\left(15^{\text {th }}\right.$ and $16^{\text {th }}$ day) of both the feeding regime.
The total expired air was collected in a Douglas bag at every half an hour interval for 4-5 min. The volume collected in Douglas bag was measured on wet test meter (precision scientific equipment U.S.A), and compositions (i.e., $\mathrm{O}_{2}$ and $\mathrm{CO}_{2}$ ) were analyzed on (iWorx LabScribe2), automatically the percentage of particular gas was displayed on LCD and memorized in the analyzer. $\mathrm{CH}_{4}$ was analyzed in expired air using methane analyzer (0.01-0.25\%), Analytical Development Co., UK, ADC.

\section{Metabolic heat production}

Metabolic heat production ( $\mathrm{kcal}$ ) was determined accurately from $\mathrm{O}_{2}$ consumption, $\mathrm{CO}_{2}$, and $\mathrm{CH}_{4}$ production. The following formula was used to determine metabolic heat production $(\mathrm{H})$.

$$
\begin{aligned}
& \mathrm{H}=3.866 \times \mathrm{O}_{2}+1.200 \times \mathrm{CO}_{2}-0.518 \times \mathrm{CH}_{4}- \\
& \quad 1.431 \times \mathrm{N}[8] . \\
& \text { Where, } \\
& \mathrm{H}=\text { Heat production }(\mathrm{H}, \mathrm{kcal}) \\
& \mathrm{O}_{2}=\text { Oxygen consumption }(\mathrm{L}) \\
& \mathrm{CO}_{2}=\text { Carbon dioxide }(\mathrm{L}) \\
& \mathrm{CH}_{4}=\text { Methane production }(\mathrm{L}) \\
& \mathrm{N}=\text { Quantity of urinary nitrogen excreted }(\mathrm{g}) .
\end{aligned}
$$

\section{Respiratory gas measurement}

The rate of volume of expired air was calculated from formula:

$$
\mathrm{V}_{\mathrm{E}(\mathrm{ATPS})}(\mathrm{L} / \mathrm{min})=\frac{\text { Total expired air in liter }}{\text { Respiration rate }}
$$

\section{Rate of $\mathrm{O}_{2}$ consumption} formula:

Rate of $\mathrm{O}_{2}$ consumption was calculated from

$$
\mathrm{V}_{\mathrm{O}_{2} \text { (ATPS) }}(\mathrm{L} / \mathrm{min})=\frac{\mathrm{V}_{\mathrm{E}} \times\left(\mathrm{F}_{\mathrm{IO}_{2}}-\mathrm{F}_{\mathrm{EO}_{2}}\right)}{\left(1-\mathrm{F}_{\mathrm{EO}_{2}}\right)}
$$

Where,

$\mathrm{V}_{\mathrm{O} 2}=$ The rate of oxygen consumption

$\mathrm{V}_{\mathrm{E}}^{\mathrm{O}}=$ The volume of air the subject breathes in 1 min (minute volume)

$\mathrm{F}_{\mathrm{IO} 2}=$ The fraction (percentage divided by 100) of inspired air that is oxygen, i.e. 0.2094 (Since the percentage of oxygen in room air is constant at about 20.94\%)

$\mathrm{F}_{\mathrm{EO} 2}=$ The fraction of expired air that is $\mathrm{O}_{2}$ (i.e. the percentage measured with the oxygen analyzer).

\section{Rate of $\mathrm{CO}_{2}$ production}

The Volume of $\mathrm{CO}_{2}$ produced per min was calculated using formula:

$$
\mathrm{V}_{\mathrm{CO}_{2} \text { (ATPS) }}(\mathrm{L} / \mathrm{min})=\frac{\left(\begin{array}{l}
\mathrm{V}_{\mathrm{E}} \times\left(\mathrm{F}_{\mathrm{ECO}_{2}}-\mathrm{F}_{\mathrm{ICO}_{2}}\right) \\
-\mathrm{F}_{\mathrm{ICO}_{2}} \times \mathrm{V}_{\mathrm{O}_{2}}
\end{array}\right)}{\left(1-\mathrm{F}_{\mathrm{ICO}_{2}}\right)}
$$

Where,

$\mathrm{V}_{\mathrm{CO} 2}=$ The rate of $\mathrm{CO}_{2}$ production

$\mathrm{V}_{\mathrm{E}}=$ The volume of air the subject breathes in 1 min (minute volume)

$\mathrm{F}_{\mathrm{ECO} 2}=$ The fraction of expired air that is $\mathrm{CO}_{2}$ 
$\mathrm{F}_{\mathrm{ICO} 2}=$ The fraction (percentage divided by 100 ) of inspired air that is $\mathrm{CO}_{2}$, i.e., $\mathrm{F}_{\mathrm{ICO} 2}=0.0003$ (Since a little percentage $(0.03 \%)$ of $\mathrm{CO}_{2}$ in fresh air).

\section{Rate of $\mathrm{CH}_{4}$ production}

The volume of $\mathrm{CH}_{4}$ produced per min was calculated:

$\mathrm{V}_{\mathrm{CH} 4 \text { (ATPS) }}(\mathrm{L} / \mathrm{min})=\mathrm{V}_{\mathrm{E}} \times \mathrm{F}_{\mathrm{ECH} 4}$

Where,

$\mathrm{V}_{\mathrm{CH} 4}=$ The rate of methane production

$\mathrm{V}_{\mathrm{E}}=$ The volume of air the subject breathes in 1 min (minute volume)

$\mathrm{F}_{\mathrm{ECH} 4}=$ The fraction of expired air that is $\mathrm{CH}_{4}$.

Volume of standard temperature and pressure, dry air

The $\mathrm{V}_{\mathrm{E}}, \mathrm{V}_{\mathrm{O} 2}, \mathrm{~V}_{\mathrm{CO} 2}$, and $\mathrm{V}_{\mathrm{CH} 4}$ for standard temperature and pressure, dry air (STPD) obtained from respective $\mathrm{V}_{\mathrm{E}}, \mathrm{V}_{\mathrm{O} 2}, \mathrm{~V}_{\mathrm{CO} 2}$, and $\mathrm{V}_{\mathrm{CH} 4}$ for ambient temperature and pressure, saturated (ATPS) using following formula:

$\mathrm{V}_{\mathrm{E}}(\mathrm{STPD})(\mathrm{L} / \mathrm{min})=\mathrm{V}_{\mathrm{E}}(\mathrm{ATPS}) \times 0.825$

$\mathrm{V}_{\mathrm{O} 2}^{\mathrm{E}}(\mathrm{STPD})(\mathrm{L} / \mathrm{min})=\mathrm{V}_{\mathrm{E}}(\mathrm{STPD})\left(\mathrm{F}_{\mathrm{IO}}-\mathrm{F}_{\mathrm{EO} 2}\right)$

$\mathrm{V}_{\mathrm{CO} 2}(\mathrm{STPD})(\mathrm{L} / \mathrm{min})=\mathrm{V}_{\mathrm{E}}^{\mathrm{E}}(\mathrm{STPD})$

$\mathrm{V}_{\mathrm{CH} 4}(\mathrm{STPD})(\mathrm{L} / \mathrm{min})=\mathrm{V}_{\mathrm{E}}(\mathrm{STPD}) \times\left(\mathrm{F}_{\mathrm{ECH} 4}\right)$

Where,

$\mathrm{V}_{\mathrm{O} 2}=$ The rate of oxygen consumption

$\mathrm{V}_{\mathrm{E}}=$ The volume of air the subject breathes in 1 min (minute volume)

$\mathrm{F}_{\mathrm{IO} 2}=$ The fraction (percentage divided by 100 ) of inspired air that is oxygen, i.e., 0.2094 (Since the percentage of oxygen in room air is constant at about $20.94 \%$ )

$\mathrm{F}_{\mathrm{EO} 2}=$ The fraction of expired air that is oxygen (i.e., the percentage measured with the $\mathrm{O}_{2}$ analyzer)

$\mathrm{V}_{\mathrm{CO} 2}=$ The rate of carbon dioxide production

$\mathrm{F}_{\mathrm{ECO} 2}^{\mathrm{CO} 2}=$ The fraction of expired air that is carbon dioxide

$\mathrm{F}_{\mathrm{ICO} 2}=$ The fraction (percentage divided by 100) of inspired air that is carbon dioxide, i.e. $\mathrm{F}_{\mathrm{ICO} 2}=0.0003$ (Since a little percentage $(0.03 \%)$ of $\mathrm{CO}_{2}$ in fresh air)

$\mathrm{V}_{\mathrm{CH} 4}=$ The rate of methane production

$\mathrm{F}_{\mathrm{ECH} 4}=$ The fraction of expired air that is $\mathrm{CH}_{4}$

$\mathrm{STPD}=$ Standard temperature and pressure at dry air

ATPS=Ambient temperature and pressure at saturated air.

\section{Statistical analysis}

The data analysis was carried out by SAS software, Version (9.1) of the SAS system [9]. The data were analyzed statistically for mean \pm standard error and analysis of variances.

\section{Results and Discussion}

\section{Metabolic heat production}

The result of $\mathrm{O}_{2}$ consumed, carbon dioxide $\left(\mathrm{CO}_{2}\right)$, and methane $\left(\mathrm{CH}_{4}\right)$ produced and metabolic heat production of Sahiwal and Karan Fries heifers during feeding regime- 1 and -2 have been presented in Table-1. The mean body weight and metabolic body weight $\left(\mathrm{W}^{0.75}\right)$ of Sahiwal heifers and Karan Fries heifers were significantly $(\mathrm{p}<0.01)$ higher in feeding regime- 2 as compared to feeding regime- 1 . The $\mathrm{O}_{2}$ consumption, $\mathrm{CO}_{2}$ production, and metabolic heat production of Sahiwal and Karan Fries heifers were significantly $(\mathrm{p}<0.05)$ higher in feeding regime- 2 as compared to feeding regime-1, whereas the metabolic heat production per unit metabolic body weight was higher in feeding regime-1.

In this metabolic heat production study, heat production partition was used as an index to determine heat (energy) retention. The result of this study demonstrated that cattle fed a diet that contains higher energy level $(15 \%$ by the supplementation of the molasses) according to their metabolic body size showed improved energy efficiency and energy retention and thus improved the growth rate [10]. A consequence of this greater energy retention was a decreased proportion of energy intake to energy losses in methane emission and heat production when the energy level was increased. These results indicated that increasing energy level is an important factor in improved body weight gain. The $\mathrm{O}_{2}$ consumption, $\mathrm{CO}_{2}$, and $\mathrm{CH}_{4}$ production during both the feeding regimes are the determinant factors for the metabolic heat production. This difference in $\mathrm{O}_{2}$ consumption, $\mathrm{CO}_{2}$, and $\mathrm{CH}_{4}$ production was mainly due to higher energy content during feeding regime-2. Tiwari et al. [11] reported that the overall daily means per unit body metabolic body weight $\left(\mathrm{kgw}^{0.75}\right)$ for $\mathrm{O}_{2}$ consumption, $\mathrm{CO}_{2}$ and $\mathrm{CH}_{4}$ production, and heat production were $17.03 \mathrm{~L}, 11.7 \mathrm{~L}, 0.12 \mathrm{~L}$, and $331 \mathrm{KJ}$, respectively, in growing buffalo calves, which indicated that a low-quality diet increased energy loss. Sauvant and Giger-Reverdin [12] suggested that feeding level influenced the ration of $\mathrm{ME}$ to GE, indicating that increased energy level or molasses supplementation could improve the energetic efficiency of animals. Further, recent research in a temperate zone [2] indicated that increasing the energy level and/or feeding additive concentrated supplements can improve energetics efficiency and thus improves animal growth and performance.

This study indicated that an increased in energy intake increased the energy efficiency and reduced the metabolic heat production per unit metabolic body weight. It also indicated that Sahiwal produces less metabolic heat production as compared to Karan Fries heifers that confer the ability of the indigenous breed to withstand the hot, humid condition of the tropical zone is higher than the crossbred animals.

\section{Energy loss as methane}

The results of methane $\left(\mathrm{CH}_{4}\right)$ emission, $\mathrm{CH}_{4}$ emission rate in Sahiwal and Karan Fries heifers under feeding regime- 1 and -2 have been presented in Table-2. The level of energy loss as methane in Sahiwal and Karan Fries heifers was found to be higher during 
Table-1: Metabolic heat production of Sahiwal and Karan Fries heifers during two different feeding regimes.

\begin{tabular}{|c|c|c|c|c|}
\hline \multirow[t]{2}{*}{ Parameters } & \multicolumn{2}{|c|}{ Sahiwal } & \multicolumn{2}{|c|}{ Karan Fries } \\
\hline & Feed-1 & Feed-2 & Feed-1 & Feed-2 \\
\hline Body weight (kg) & $167.50 \pm 4.08$ & $221.50 \pm 7.91 * *$ & $221.83 \pm 15.63$ & $297.00 \pm 13.47 * *$ \\
\hline Metabolic body weight $(\mathrm{kg})$ & $46.54 \pm 0.85$ & $57.38 \pm 1.53 * *$ & $57.34 \pm 3.05$ & $71.47 \pm 2.43 * *$ \\
\hline Basal metabolic rate $(\mathrm{kg})$ & $3023.36 \pm 54.20$ & $3710.45 \pm 96.89 * *$ & $3707.61 \pm 193.51$ & $4599.94 \pm 153.66 * *$ \\
\hline Respiration rate (bpm) & $21.50 \pm 0.56$ & $22.83 \pm 0.40$ & $24.33 \pm 0.98$ & $26.33 \pm 0.88$ \\
\hline Tidal volume $(\mathrm{L})$ & $2.27 \pm 0.07$ & $2.18 \pm 0.07$ & $2.20 \pm 0.13$ & $2.17 \pm 0.12$ \\
\hline Calculating time $(\mathrm{min})$ & $3.94 \pm 0.12$ & $3.81 \pm 0.14$ & $3.76 \pm 0.24$ & $3.60 \pm 0.25$ \\
\hline Volume in Douglas bag $(\mathrm{L})$ & $188.21 \pm 0.52$ & $188.76 \pm 1.57$ & $196.70 \pm 2.35$ & $201.36 \pm 1.46$ \\
\hline $\mathrm{V}_{\mathrm{E}}(\mathrm{ATPS})(\mathrm{L} / \mathrm{min})$ & $48.83 \pm 1.50$ & $49.91 \pm 2.02$ & $53.39 \pm 3.36$ & $57.17 \pm 3.66$ \\
\hline $\mathrm{V}_{\mathrm{O} 2}(\mathrm{ATPS})(\mathrm{L} / \mathrm{min})$ & $1.00 \pm 0.03$ & $1.17 \pm 0.04 *$ & $1.28 \pm 0.09$ & $1.49 \pm 0.08$ \\
\hline $\mathrm{V}_{\mathrm{CO} 2}(\mathrm{ATPS})(\mathrm{L} / \mathrm{min})$ & $0.89 \pm 0.01$ & $0.99 \pm 0.03 *$ & $0.99 \pm 0.06$ & $1.11 \pm 0.07$ \\
\hline $\mathrm{V}_{\mathrm{CH} 4}(\mathrm{ATPS})(\mathrm{L} / \mathrm{min})$ & $0.05 \pm 0.001$ & $0.04 \pm 0.005$ & $0.08 \pm 0.008$ & $0.07 \pm 0.009$ \\
\hline VE (STPD) (L/min) & $40.29 \pm 1.24$ & $41.17 \pm 1.67$ & $44.04 \pm 2.77$ & $47.17 \pm 3.01$ \\
\hline $\mathrm{V}_{\mathrm{O} 2}(\mathrm{STPD})(\mathrm{L} / \mathrm{min})$ & $0.82 \pm 0.02$ & $0.96 \pm 0.03 *$ & $1.06 \pm 0.07$ & $1.23 \pm 0.07$ \\
\hline $\mathrm{V}_{\mathrm{CO} 2}(\mathrm{STPD})(\mathrm{L} / \mathrm{min})$ & $0.73 \pm 0.008$ & $0.81 \pm 0.030 *$ & $0.82 \pm 0.05$ & $0.92 \pm 0.06$ \\
\hline $\mathrm{V}_{\mathrm{CH} 4}(\mathrm{STPD})(\mathrm{L} / \mathrm{min})$ & $0.04 \pm 0.001$ & $0.03 \pm 0.004$ & $0.06 \pm 0.007$ & $0.06 \pm 0.007$ \\
\hline $\mathrm{HP} / \min (\mathrm{kcal})$ & $4.06 \pm 0.11$ & $4.70 \pm 0.17^{*}$ & $5.31 \pm 0.21$ & $5.99 \pm 0.21 *$ \\
\hline $\mathrm{HP} /$ day (kcal) & $5858.01 \pm 163.30$ & $6779.90 \pm 250.37 *$ & $7653.67 \pm 304.36$ & $8634.67 \pm 312.91 *$ \\
\hline $\mathrm{HP} /$ metabolic body weight $\left(\mathrm{kcal} / \mathrm{kg}^{0.75}\right.$ ) & $125.92 \pm 3.23$ & $118.20 \pm 3.48$ & $134.83 \pm 7.20$ & $120.76 \pm 0.43$ \\
\hline
\end{tabular}

$* \mathrm{p}<0.05$ and $* * \mathrm{p}<0.01$ differ significantly at $5 \%$ and $1 \%$ level, respectively, within breed. STPD=Standard temperature and pressure, ATPS $=$ Ambient temperature and pressure, $\mathrm{HP}=$ Heat production

Table-2: Methane emission by Sahiwal and Karan Fries heifers during two different feeding regimes.

\begin{tabular}{|c|c|c|c|c|}
\hline \multirow[t]{2}{*}{ Parameters } & \multicolumn{2}{|c|}{ Sahiwal } & \multicolumn{2}{|c|}{ Karan Fries } \\
\hline & Feed-1 & Feed-2 & Feed-1 & Feed-2 \\
\hline Body weight (kg) & $167.50 \pm 4.08$ & $221.50 \pm 7.91 * *$ & $221.83 \pm 15.63$ & $297.00 \pm 13.47 * *$ \\
\hline Metabolic body weight (kg) & $46.54 \pm 0.85$ & $57.38 \pm 1.53 * *$ & $57.34 \pm 3.05$ & $71.47 \pm 2.43 * *$ \\
\hline Basal metabolic rate $(\mathrm{kg})$ & $3023.36 \pm 54.20$ & $3710.45 \pm 96.89 * *$ & $3707.61 \pm 193.51$ & $4599.94 \pm 153.66 * *$ \\
\hline Mean\% $\mathrm{CH}_{4}$ & $0.10 \pm 0.001$ & $0.09 \pm 0.009$ & $0.15 \pm 0.012$ & $0.13 \pm 0.008$ \\
\hline $\mathrm{V}_{\mathrm{CH} 4}(\mathrm{ATPS})(\mathrm{L} / \mathrm{min})$ & $0.05 \pm 0.001$ & $0.04 \pm 0.005$ & $0.08 \pm 0.008$ & $0.07 \pm 0.009$ \\
\hline $\mathrm{V}_{\mathrm{CH} 4}(\mathrm{STPD})(\mathrm{L} / \mathrm{min})$ & $0.04 \pm 0.001$ & $0.03 \pm 0.004$ & $0.06 \pm 0.007$ & $0.06 \pm 0.007$ \\
\hline $\mathrm{CH}_{4}$ (L/day) & $62.20 \pm 1.74$ & $56.93 \pm 7.01$ & $100.55 \pm 10.59$ & $92.49 \pm 11.32$ \\
\hline Energy loss as $\mathrm{CH}_{4}(\mathrm{kcal} / \mathrm{min})$ & $0.40 \pm 0.01$ & $0.37 \pm 0.04$ & $0.65 \pm 0.06$ & $0.60 \pm 0.07$ \\
\hline Energy loss as $\mathrm{CH}_{4}(\mathrm{kcal} /$ day $)$ & $587.81 \pm 16.46$ & $538.03 \pm 66.32$ & $950.26 \pm 100.12$ & $874.06 \pm 107.00$ \\
\hline $\mathrm{CH}_{4} * 9.45(\mathrm{kcal}) / \mathrm{HP}(\mathrm{kcal} / \mathrm{min})$ & $10.04 \% \pm 0.18$ & $7.85 \% \pm 0.81 *$ & $12.36 \% \pm 1.02$ & $9.98 \% \pm 0.91$ \\
\hline
\end{tabular}

$* p<0.05$ and $* * p<0.01$ differ significantly at $5 \%$ and $1 \%$ level, respectively, within breed. STPD $=$ Standard temperature and pressure, ATPS $=$ Ambient temperature and pressure, $\mathrm{HP}=$ Heat production

feeding regime-1 as compared to feeding regime-2. Methane emission rate, the proportion of gross energy intake that is released as enteric methane energy $(\%$ GEI), is a critical factor used to assess the potential extent of global warming in national inventories and enteric methane estimation [13]. These experimental results suggest that the methane emission rate (ranging from $7.3 \%$ to $11.5 \%$ ) of Brahman cattle that are maintained in a tropical beef production feeding system [2]. Johnson and Johnson [6] also reported a methane energy loss of $6-7 \%$ of gross energy intake when forage was fed, and this reduces to $2-3 \%$ when high grain concentrate was offered at near ad-libitum intake level.

The result of this study was in consistent of Hammond et al. [14] that reported a high methane emission rate of cattle fed high fiber feedstuff based diets. The typically poor quality feed available in our tropical condition may be the main factor affecting methane emission rate. Improving feed quality by supplementation with feed additive, i.e., molasses or increasing the energy level of the ration of the animals was helpful in reduction in methane emission rate. Our results indicate that digestibility of feedstuffs and rate of passage may increase with increasing energy level of the feed that decrease the opportunity for degradation of potentially degradable NDF; consequently, methane emission rate is decreased [15]. The result of this study are in accordance to those of Chaokaur et al. [10], who reported $8 \%$ and $11.5 \%$ energy loss as methane when animals were maintained on higher and lower level of feeding, respectively. This study also indicated that the methane emission rate was more in Karan Fries than Sahiwal heifers. This indicates that our indigenous breeds are more adapted to our climatic condition than the crossbred and impart less global warming.

\section{Conclusion}

Based on this study, it can be concluded that feeding of extra energy (15\%) by the addition of molasses in the feed of Sahiwal and Karan Fries heifers helped 
in reduction of metabolic heat production $/ \mathrm{W}^{0.75}$ and energy loss in terms of methane production. This reduction in enteric methane emission loss will be helpful in reduction of global warming.

The study further showed that Sahiwal heifers contribute less methane emission to the environment as compared to Karan Fries (crossbred) maintained on the same feeding schedule, indicating the importance of zebu cattle toward the lesser global warming. By improving the feeding of ruminant animals may help in two ways, i.e., more availability of energy for productive process and lesser global warming.

\section{Authors' Contributions}

SVS has planned the study. SK conducted the experiment and recorded the $\mathrm{O}_{2}, \mathrm{CO}_{2}$, and $\mathrm{CH}_{4}$ emission in expired air. SK and PP estimated the metabolic heat production and methane emission based on recorded data. SK, SVS, and OKH performed statistical analysis. SK and NK drafted and revised the manuscript under the guidance of SVS. All authors read and approved the final manuscript.

\section{Acknowledgments}

The authors express sincere thanks to the Director, ICAR-NDRI, Karnal, for providing all necessary facilities for conducting research work. The authors acknowledge the NICRA project for financial help to carry out this research work.

\section{Competing Interests} interests

The authors declare that they have no competing

\section{References}

1. Blaxter, K. (1989) Energy Metabolism in Animals and Man. Cambridge University Press, Cambridge.

2. Staerfl, S.M., Zeitz, J.O., Kreuzer, M. and Soliva, C.R. (2012) Methane conversion rate of bulls fattened on grass or maize silage as compared with the IPCC default values, and the long-term methane mitigation efficiency of adding acacia tannin, garlic, maca and lupine. Agric. Ecosyst. Environ., 148: 111-120.

3. Tangjitwattanachai, N., Phaowphaisal, I., Otsuka, M. and Sommart, K. (2015) Enteric methane emission, energetic efficiency and energy requirements for the maintenance of beef cattle in the tropics. Jpn. Agric. Res. Q., 49(4): 399-407.

4. Chagunda, M.G.G. (2013) Opportunity and challenges in the use of the laser methane detector or monitor enteric methane emission from ruminants. Anim. Consort. Anim., 7(52): 392-400.

5. Phromloungsri, A., Hayashi, K., Otsuka, M., Udchachon, S. and Sommart, K. (2012) Effects of energy intake level on methane production of Thai native and Brahaman crossbred cattle. Khon Kaen Agric. J., 40: 5-11.

6. Johnson, K.A. and Johnson, D.E. (1995) Methane emissions from cattle. J. Anim. Sci., 73: 2483-2492.

7. National Research Council. (2001) Nutrient Requirements of Dairy Cattle. $7^{\text {th }}$ Rev. ed. National Academy of Sciences, Washington, DC.

8. Brouwer, E. (1964) Report of sub - Committee on constant and factors. In Energy metabolism. In: Blaxter, K.L., editor. European Association for Animal Production Publication No. 11. p441-443.

9. SAS, Institute. (2011) Statistical Analysis System. Version 9.1. SAS Institute, Cary, NC, USA.

10. Chaokaur, A., Nishida, T., Phaowphaisal, I. and Sommart, K. (2015) Effects of feeding level on methane emission and energy utilization of Brahman cattle in the tropics. Agric. Ecosyst. Environ., 199: 225-230.

11. Tiwari, C.M., Jadhao, S.B. and Khan, M.Y. (2000) Fasting heat production of growing buffalo calves. Asian-Aust. J. Anim. Sci., 13(3): 307-312.

12. Sauvant, D. and Giger-Reverdin, S. (2007) Empirical modeling by meta-analysis of digestive interactions and CH4 production in ruminants. In: Ortigues-Marty, I., Miraux, N., Brand-Williams, W., editors. Energy and Protein Metabolism and Nutrition. EAAP Publication No. 124. Wageningen Academic Publication, Wageningen, The Netherlands, p561-562.

13. Gerber, P.J., Steinfeld, H., Henderson, B., Mottet, A., Opio, C., Dijkman, J., Falcucci, A. and Tempio, G. (2013) Tackling Climate Change Through Livestock - A Global Assessment of Emissions and Mitigation Opportunities. Food and Agriculture Organization of the United Nations (FAO), Rome.

14. Hammond, K.J., Humphhries, D.J., Westbury, D.B., Thompson, A., Crompton, L.A., Kirton, P., Green, C. and Reynolds, C.K. (2014) The inclusion of forage mixture in the diet of growing dairy heifers: Impacts on digestion, energy utilization and methane emissions. Agric. Ecosyst. Environ., 197: 88-95.

15. Blaxter, K.L. and Clapperton, J.L. (1965) Prediction of the amount of methane produced by ruminants. Br. J. Nutr., 19: $511-522$. 